УДК 656.2.001.73(100) (477)

\title{
ЗАРУБІЖНИЙ ТА ВІТЧИЗНЯНИЙ ДОСВІД ФОРМУВАННЯ СТРАТЕГІЇ РОЗВИТКУ ЗАЛІЗНИЧНОГО ТРАНСПОРТУ В КОНТЕКСТІ РЕФОРМУВАННЯ УКРЗАЛІЗНИЦІ
}

\author{
Дейнека О.Г., д.е.н., професор, \\ Бондарев Ю.С., магістрант програми ТЕМПУС (УкрДУЗТ)
}

\begin{abstract}
В статті розкриваються напрямки формування стратегї розвитку залізниць. Метою статті є систематизачія теоретичних $i$ практичних підходів залізничних адміністрачій крайн Євросоюзу щодо організації швидкісного руху. Розглянуто як теоретичні підходи реорганізацій залізниць, так і практичні кроки до реалізачії изих варіантів. Моделі реформування залізниць світу розглянуто під кутом зору можливостей реалізацій ПАТ «Українська залізниця»

Ключові слова: реформування, стратегія залізничного транспорту, криза, інструменти управління, ефективність, конкуренція, прибутковість.
\end{abstract}

\section{ЗАРУБЕЖНЫЙ И ОТЕЧЕСТВЕННЫЙ ОПЫТ ФОРМИРОВАНИЯ СТРАТЕГИИ РАЗВИТИЯ ЖЕЛЕЗНОДОРОЖНОГО ТРАНСПОРТА В КОНТЕКСТЕ РЕФОРМИРОВАНИЯ УКРЗАЛИЗНЫЦИ}

Дейнека А.Г., д.э.н., профессор,

Бондарев Ю.С., магистрант программы ТЕМПУС (УкрГУЖТ)

B статье раскрываются направления формирования стратегии развития железных дорог. Целью статьи является систематизация теоретических и практических подходов железнодорожных администраций стран Евросоюза по организации скоростного движения. Рассмотрены как теоретические варианты реорганизаций железных дорог, так и практические шаги к реализации этих вариантов. Модели реформирования железных дорог мира рассмотрено с точки зрения возможностей реализаџии ПАО «Украинская железная дорога»

Ключевые слова: реформирование, стратегия жселезнодорожнного транспорта, кризис, инструменты управления, эффективность, конкуренция, прибыльность.

\section{FOREIGN AND DOMESTIC EXPERIENCE IN FORMING A STRATEGY FOR THE DEVELOPMENT OF RAIL TRANSPORT IN THE CONTEXT OF THE REFORM OF THE PJSC "'UKRAINIAN GULF" ARE DISCLOSED}

\author{
Deineka A., doctor of Economics, Professor, \\ Bondarev Y., Master of program TEMPUS (USURT)
}

The article reveals the directions of formation of the railway development strategy. The purpose of the article is to systematize theoretical and practical approaches of the

(C) Дейнека О.Г., Бондарев Ю.С.
Вісник економіки транспорту і промисловості № 59, 2017 
railway administrations of the European Union countries regarding the organization of highspeed traffic. Considered as theoretical variants of railway reorganizations, as well as practical steps to implement these options. Models of the reformation of the railways of the world are considered from the perspective of the possibilities of realization of the PJSC "Ukrainian gulf are disclosed

Keywords: reform, railway transport strategy, crisis management tools, efficiency, competition, profitability.

\section{Постановка}

Реформування залізничного транспорту України має першочергове значення, що визначить інтеграцію його до європейських транспортних мереж. Чисельні варіанти реформування залізниць, що мали місце в Україні на протязі останніх двадцяти років, нажаль, реалізовані не були. Це було наслідком незваженої 3 економічної точки зору політики державних структур, що не підкріплювались ретельним розрахунком та відсутністю інвестиційних складових Нечітко ставилися завдання відносно першочергового розвитку швидкісних i високошвидкісних магістралей, відокремлення фінансової складової пасажирських і приміських сполучень від вантажних, тощо. Таким чином криза залізниць світу значно негатив ніше проявляла себе на Українських залізницях. Як відомо більшість залізниць світу в 7080-х pp. ХХ століття зіткнулися з тим, що темпи поглиблення проблем, що стоять перед залізничним транспортом, стали випереджати темпи оновлення та розвитку галузі. Швидке накопиченнявнутрішньо системних порушень загрожувало лавиноподібним наростанням різних дефектів (технологічних збоїв, аварій, зниженням якості послуг, що надаються), це стало серйозною перешкодою для збереження гарантованого рівня надійності, безпеки та ефективності функціонування залізниць.

Криза залізничного транспорту у всьому світі була пов'язана із зміною технологічної парадигми і проблемами, що виникли через не конкурентоспроможність залізниць в порівнянні 3 новими видами транспорту через багато разове зростання витрат для підтримки й відновлення інфраструктури залізниць

Аналіз публікацій. Останні роки вийшли у світ чисельні публікації за цією тематикою. На початку етапу реформування українських залізниць доцільно ознайомитися 3 метою часткового залучення зарубіжного досвіду. Саме цій проблемі присвячена публікація. Значна кількість публікацій присвячена питанням розвитку залізничного транспорту, його реформування i організації швидкісного руху. В них розглядається великий комплекс проблем , що виникли. Так Б.Іванов [1] критикує модель реформування залізниць Великої Британії, яка привела до зниження обсягів перевезень. В статті "Реформы на железных дорогах, Бельгии вказано, що в найближчі кілька років національне товариство залізниць Бельгії ( $\mathrm{SNCB}$ ) може втратити статус монополіста [2], JI. Позднякова констатувала, що утворення компанії "Российские железные дороги призвело до ще більшої централізації управління господарською діяльністю [3]. Вчена зробила аналіз структурних перетворень на залізницях світу [4], Ю. Бараш аналізує умови розвитку європейських залізниць після прийняття декларацій Свропейського союзу стосовно побудови організаційних структур управління транспортом [5]. Своє бачення проблеми впровадження високошвидкісного руху Укрзалізниця виклала у відповідній Концепції [6].

Вісник економіки транспорту і промисловості № 59, 2017 
Чисельні публікації інших фахівців і вчених залізничних ВНЗ Харкова, Дніпра та Києва присвячені питанням реформування залізничного транспорту України та організації швидкісного i високошвидкісного руху. Разом 3 тим зазначені питання, ще і досі є предметом гострих дискусій і чисельних публікацій.

Метою статті $\epsilon$ систематизація теоретичних i практичних підходів залізничних адміністрацій країн Євросоюзу щодо організації швидкісного руху в Україні. Залучення позитивних результатів реформування залізниць світу дозволить ПАТ «Українська залізниця» вийти із системної кризи і стати на рівень рентабельності пасажирських перевезень. Деякі принципові питання цього наведені у статті.

Викладення основного матеріалу. У більшості зарубіжних країн першим кроком для вирішення цих проблем стало проведення реформ залізничного транспорту, тобто розпочався процесс реформування.

Реформування - це процес зміни напрямків діяльності, який пов'язаний зі становленням ринкової економіки та зміною соціально - економічних умов функціонування. Він включає реформування відносин власності (реорганізацію, корпоратизацію, реструктуризацію, приватизацію) та адаптацію цілей, стратегії, політики i організаційної структури управління до нових умов функціонування в умовах ринкової економіки.

Здійснення процесу реформування неможливо без обгрунтованої та зафіксованої у виді окремого документу стратегії розвитку. Тобто, початковим етапом процесу реформування $\epsilon$ встановлення місії, визначення основних цілей та напрямків розвитку. Для реалізації процессу реформування на залізничному транспорті, зокрема, країн Європейського союзу, також застосовували наступні стратегіï розвитку: реорганізація, корпоратизація, реструктуризація та приватизація. $\mathrm{У}$ зв'язку 3 цим було розроблено стандартизований набір інструментів управління. Цей вибір включає в себе методи розділення функцій державного регулювання та управління господарською діяльністю, виділення природно-монопольних i конкурентних секторів, регулювання видів діяльності, які не є природно - монопольними, процедури переходу від монопольного стану галузі

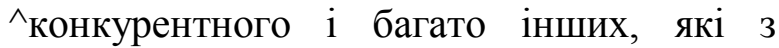
більшим чи меншим успіхом використовуються протягом останніх 2030 років. Потреба у реформуванні підприємств залізничного транспорту обумовила розроблення п'яти загальних стратегічних варіантів реорганізації залізниць, які вперше у наукових публікаціях були запропоновані Д. Мойєром [7].

До теоретичних варіантів реорганізації залізниць відносяться: унітарна залізниця; орієнтація залізниць на конкретні види обслуговування; конкурентний підхід;оптовий підхід;стягнення плати за використання .

Рішення про перевагу якогось варіанта $\epsilon$ питанням вибору між ефективністю транспорту ефективністю задоволення потреб ринку. Рейтинг варіанта унітарної залізниці високий 3 точки зору технічної ефективності, оскільки експлуатаційні конфлікти вирішуються директивно. Варіант орієнтації на конкретні види обслуговування характеризуються кращою спроможністю реагувати на ринкові зміни та аналізувати доходи і витрати за видами обслуговування, але відрізняється більш високою вірогідністю експлуатаційних конфліктів і витрат з реорганізації.

Варіант конкурентного підходу вводить конкуренцію усередині галузі на окремих ринках при збереженні єдиного управління більшістю залізничних

Вісник економіки транспорту і промисловості № 59, 2017 
операцій. Але такий варіант часто $\epsilon$ процесом еволюційним. Варіант оптового підходу передбачає високу компетенцію служб маркетингу, але функції експлуатації повинні залишатися в єдиних руках. Варіант «стягнення плати за використання» ближчий за інші до теоретичної моделі ефективного маркетингу, але відрізняється високою вірогідністю експлуатаційних конфліктів і витрат. Цей варіант потребує значних зусиль в управлінні з боку державних структур [8]. У реальних умовах складні поєднання методів експлуатації, видів обслуговування і особливостей географічних зон, які характеризують розвинуті залізничні системи, можуть вимагати складної комбінації можливих варіантів реорганізації. Найбільш поширеними варіантами реорганізації системи управління в країнах світу стали: вертикальне або горизонтальне розділення. При такому підході, власність на інфраструктуру відокремлюється від власності на перевезення. Переважна форма конкуренції при такому підході - це конкуренція між операторами перевізниками. Ці компанії у свою чергу можуть бути розділені горизонтально, і конкуренція на різних сегментах може бути дозволена.

Найбільш часті приклади такого роду поділу були здійснені у Великобританії та Швеції, - вертикальна інтеграція 3 регульованим доступом. У цьому випадку базовий оператор залізниць залишається вертикально інтегрованим (хоча може мати місце часткове горизонтальне розділення). При цьому конкуруючі оператори перевізники отримують право доступу до інфраструктури базового оператора на регульованих умовах. Основна форма конкуренції при цьому підході конкуренція між компаніями перевізниками, які не володіють доступом до інфраструктури, а також між ними та інтегрованим базовим оператором; вертикальна інтеграція (з горизонтальним поділом). У цьому підході базовий інтегрований залізничний оператор поділяється на кілька

Таблиия 1

Моделі реформування залізниць розвинутих країн світу

\begin{tabular}{|c|c|c|c|c|}
\hline \multirow[t]{2}{*}{ Модель } & \multirow{2}{*}{\begin{tabular}{l}
\multicolumn{1}{c}{ Країни } \\
основні \\
представники
\end{tabular}} & \multirow{2}{*}{ 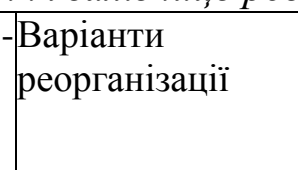 } & \multicolumn{2}{|c|}{ Форма власності на перевезення } \\
\hline & & & вантажів & пасажирів \\
\hline $\begin{array}{l}\text { Американська } \\
\text { модель }\end{array}$ & СІЛА & $\begin{array}{l}\text { Вертикальна } \\
\text { iнтеграція } \\
\text { регульованим } \\
\text { доступом }\end{array}$ & $\begin{array}{l}\text { Приватні } \\
\text { зоператори }\end{array}$ & $\begin{array}{l}\text { Державні } \\
\text { компанії }\end{array}$ \\
\hline \multirow[t]{3}{*}{$\begin{array}{l}\text { Свропейська } \\
\text { модель }\end{array}$} & $\begin{array}{l}\text { Німеччина, Італія, } \\
\text { Австрія }\end{array}$ & $\begin{array}{l}\text { Вертикальна } \\
\text { інтеграція } \\
\text { горизонтальним, } \\
\text { розділенням }\end{array}$ & \multirow[t]{2}{*}{$\begin{array}{l}\text { Приватні та } \\
\text { 3ержавні } \\
\text { оператори }\end{array}$} & \multirow[t]{2}{*}{$\begin{array}{l}\text { Державні } \\
\text { компанії } \\
\text { далеких } \\
\text { сполученнях }\end{array}$} \\
\hline & Іспанія & $\begin{array}{l}\text { Горизонтальне } \\
\text { розділення }\end{array}$ & & \\
\hline & Великобританія & $\begin{array}{l}\text { Горизонтальне } \\
\text { розділення }\end{array}$ & $\begin{array}{l}\text { Приватні } \\
\text { оператори }\end{array}$ & $\begin{array}{l}\text { Приватні } \\
\text { оператори }\end{array}$ \\
\hline $\begin{array}{l}\text { Унітарна } \\
\text { модель }\end{array}$ & $\begin{array}{l}\text { Росія, } \quad \text { Україна, } \\
\text { країни } \\
\text { Азії }\end{array}$ & & $\begin{array}{l}\text { Державні } \\
\text { компанії }\end{array}$ & $\begin{array}{l}\text { Державні } \\
\text { компанії }\end{array}$ \\
\hline
\end{tabular}

Вісник економіки транспорту і промисловості № 59,2017 
\begin{tabular}{lll}
\multicolumn{1}{c}{ залізничної } & галузі & України \\
європейське & та & національне
\end{tabular} законодавство. законодавство По
Європейське залізничному

транспорту містить пакет директив $\mathrm{CC}$, вимоги яких $€$ обов'язковими для виконання країнами - кандидатами на вступ до ЄС:[9] -директива Європейського парламенту 1 Ради 2001/12/СС від 26 лютого 2001 яка доповнює та змінює Директиву 91/440/СС по розвитку залізниць; компаній, що володіють певним набором маршрутів. У цьому випадку головні форми конкуренції - паралельна конкуренція (за наявності паралельних шляхів, що належать різним компаніям) i конкуренція вибору вантажовідправником пункту доставки (ринку збуту його товару) разом з вибором перевізника. Крім того, кожен оператор може встановити угоди 3 іншими операторами про взаємне надання своїх шляхів для руху поїздів конкурента: В умовах об'єднаної або загальної власності інфраструктура природної монополії (або частина іiі) знаходиться у спільній власності компаній - операторів поїздів. На практиці такий підхід до цих пір використовувався лише стосовно деяких обслуговуючих структур (таких як центральний вокзал у Мехіко або ключові ділянки колії). Розглянуті підходи не $\epsilon$ несумісними. Можливо, наприклад, відділення інфраструктури від вантажних перевезень при збереженні інтеграції 3 пасажирськими послугами(як це має місце в Японії).

Практичний досвід роботи залізниць світу показав, що на базі відомих моделей кожною країною розроблялися власні моделі, котрі враховували національні умови та реалізовували поставлені завдання. Так, у світовій практиці з'явились наступні моделі: - американська модель - наявність декількох вертикально інтегрованих компаній які конкурують на одних і тих

же напрямках; європейська модель - єдина инфраструктура відокремлена від перевізної діяльності. Перевізники конкурують або «на коліях», або за право доступу до інфраструктури; унітарна модель - залізниці $є$ державною монополією. Моделі реформування залізниць розвинутих країн світу наведені у табл. $1.1 \mathrm{У}$ відповідності до обраного курсу України на інтеграцію в СС реформування залізничного транспорту має бути спрямоване на майбутню інтеграцію залізниць України в загальноєвропейську залізничну мережу. Це $\epsilon$ подальший вибір європейського варіанту реформування залізничного транспорту України. У зв'язку 3 цим правовою основою реформування директива 2001/13/СС Свропейського парламенту та Ради від 26 лютого2001 року, яка доповнює та змінює Директиву 95/18/СС Ради по ліцензуванню залізничних підприємств; директива 2001/14/ЄЄ Європейського парламенту та Ради від 26 лютого 2001року про розподіл пропускної спроможності залізничної інфраструктури, стягування плати за користування залізничною інфраструктурою та сертифікації на відповідність вимогам безпеки. Основні положення Директиви Свропейського парламенту I Ради 2001/12 СС від 26 лютого 2001 року (яка доповнюе та змінює Директиву91/440 ЄС по розвитку залізниць) вимагають від залізничних адміністрацій забезпечення справедливого i рівноправного доступу до залізничної інфраструктури всім ліцензованим залізничним підприємствам, виконуючих вимоги безпеки. При цьому інституціональне відокремлення інфраструктури від експлуатаційної діяльності $€$ необов'язковим, але обов'язково мають бути розділені рахунки доходів та витрат й бухгалтерських балансів, а витрати по утриманню та експлуатації інфраструктури відокремлені

Вісник економіки транспорту і промисловості № 59, 2017 
від витрат на перевезення. Директива 2001/13/ЄС Свропейського парламенту та Ради від 26 лютого 2001року, яка доповнює та змінює Директиву 95/18/ЄС, надає умови ліцензування 3 метою забезпечення дії права доступу до залізничної інфраструктури залізничних підприємств. Директива 2001/14/СС Свропейського парламенту та Ради від 26 лютого 2001року формує принципи розподілу пропускної спроможності залізничної інфраструктури, забезпечення оптимальних режимів використання залізничної структури, стягування плати за користування залізничною інфраструктурою та сертифікації рухомого складу i інших основних виробничих фондів на відповідність вимогам безпеки.

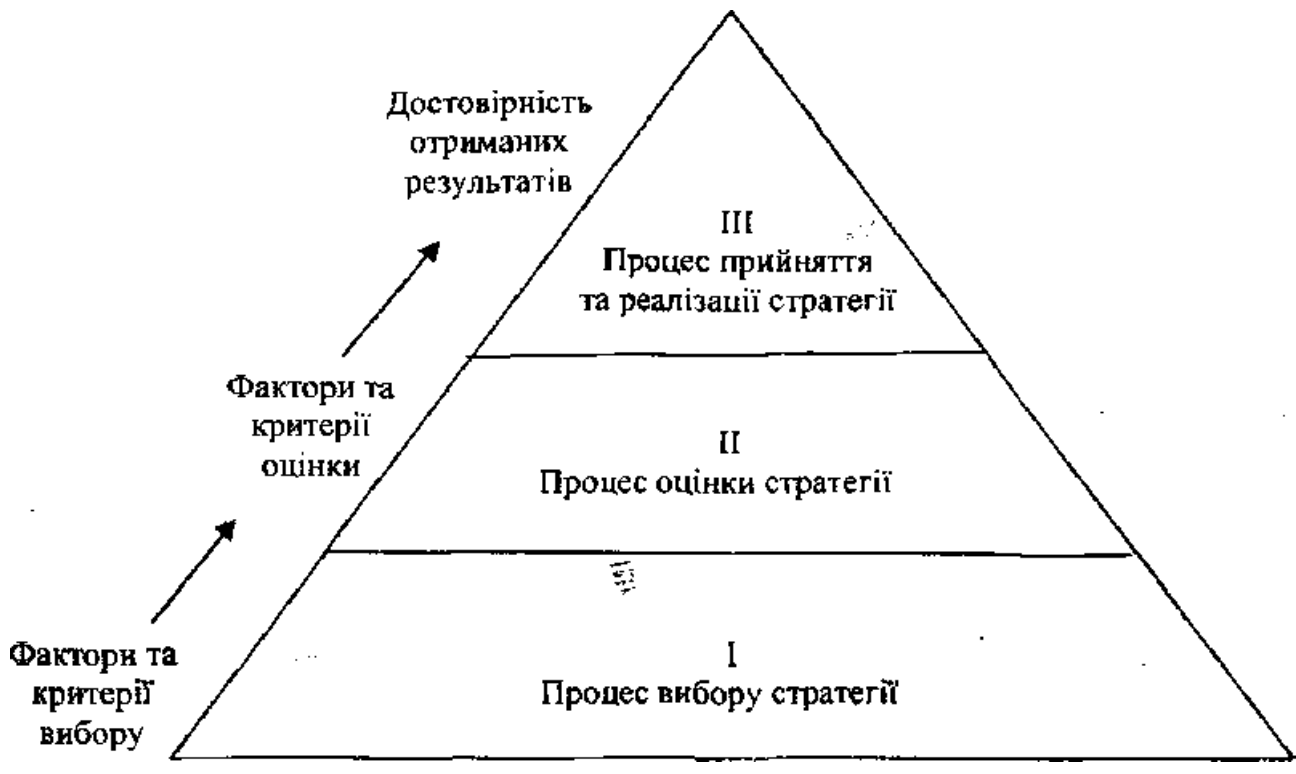

Рис. 1.1 Основні етапи реформування залізниць в краӥнах $Є C$

Це підтверджувалось Законом про акціонування залізничного транспорту України від 23.02.2012 р., який також передбачав реалізацію реформування у три етапи: 1 етап(2012-2013 рр.) створення єдиної державної акціонерної компанії 3 розділенням функцій між державою та акціонерною залізничною компанією; 2 етап (2013-2015 рр.) створення вертикально-інтегрованої виробничо-технологічної системи залізничного транспорту, структурованої за видами діяльності. На етапі стратегії реструктуризації на державу покладені такі функції:

$$
\text { - управління та фінансування }
$$
розвитку транспортної інфраструктури;
- вирішення питання про заборгованість залізниць перед державою;

- забезпечення рівного доступу незалежних компаній - операторів до залізничної інфраструктури;

- встановлення пільгових тарифів та компенсування залізницям можливих збитків від їх застосування;

- сприяння створенню самостійних залізничних компаній - операторів 3 метою розвитку внутрішньої $\mathrm{i}$ міжгалузевої конкуренції. Залізниці 3 свого боку при реалізації даної стратегії мають виконувати такі функції:

$$
\text { - управління рухом }
$$

Вісник економіки транспорту і промисловості № 59, 2017 
- організація

пасажирів, вантажів, пошти;

- утримання i

інфраструктури;

- здійснення допоміжної діяльності.

3 етап (2016-2019 рр.) - буде ліквідоване перехресне субсидування пасажирських перевезень за рахунок вантажних i створено господарське товариство у сфері пасажирських перевезень. На етапі приватизації здійснюється переведення діяльності залізничної галузі на комерційні засади, а саме:

- відмова від адміністративних та перехід до економічних методів управління на основі прибутковості перевезень;

- використання маркетингових принципів у взаємодії з користувачами послуг підвищення на цій базі прибутковості і конкурентної привабливості транспортних послуг.

Порівнюючи основні етапи реформування залізничної галузі, які відбулися в країнах $\mathrm{CC}$ та зараз реалізуються в Україні видно, що вони мають схожу структуру i націлені на однаковий результат, що підтверджується інтеграційним курсом нашої держави у світову транспортну систему. Як показує досвід роботи закордонних залізниць, початковим етапом процессу реформування $\epsilon$ визначення відповідних стратегічних напрямків та пріоритетів. Ураховуючи інтеграційний курс нашої держави необхідно проаналізувати сучасні пріоритети стратегічного розвитку Європейського залізничного транспорту, основними 3 яких є створення системи комплексного

обслуговування 3 використанням механізмів маркетингу та інтеграція у діяльність міжнародних логістичних ланцюгів, які передбачають: підпорядкування технології перевізного процесу вимогам маркетингу та логістики, що передбачає своєчасну доставку вантажів, забезпечення їх збереження, високу швидкість, швидку реакцію на вимоги клієнтури, можливість доставки вантажу за принципом «від дверей до дверей», гнучкі тарифи;

- розробка системи оцінки якості обслуговування (графіки, строки доставки, інформаційне забезпечення, надійність транспортних коштів);

- розвиток міжнародного транзиту, який $є$ складовою сучасних міжнародних економічних відносин між різними країнами;

створення транспортних коридорів, з'єднуючих важливі пункти відправлення та призначення, по яким слідують пріоритетні вантажні поїзди 3 встановленим часом виконання операцій та фіксованим прибуттям до пунктів призначення;

$$
\text { - подальший розвиток }
$$
відправницької маршрутизації, яка охоплює основний обсяг масових вантажів, введення одно - та двохгрупових поїздів підвищеної транзитності;

$$
\text { - скорочення переробки }
$$

вагонопотоків на шляху прямування;

- впровадження системи перевезень (типу «Карго»), за якою контейнерні поїзди курсують між терміналами не застосовуючи маневрові операції i переробку на сортувальних станціях;

- розвиток системи регулярних міжнародних перевезень 3 гарантованим терміном поставки вантажів: протягом ночі - на відстань 200-300 км. однієї доби 750км.і двох діб - 1500 км (Європа);

$$
\text { - більш повне використання }
$$
потенціалу, комбінованих залізничноавтомобільних перевезень контейнерів i контрейлерів обмінних рефрижераторних кузовів зі швидкопсувними вантажами;

$$
\text { - організація перевезень }
$$

контейнерів маршрутними поїздами згідно

Вісник економіки транспорту і промисловості № 59, 2017 
системи «континентальний міст» 3 пробігом 1500-1600 км на добу, завантаженням контейнерів у два яруси;

створення комп'ютерних центрів управління перевезеннями з вирішеннями комплексу експлуатаційних задач.

На ці європейські пріоритетні напрямки розвитку залізничної галузі повинна орієнтуватися і наша країна при розробленні відповідних стратегічних напрямків 3 розвитку залізничного транспорту України. Так у 2009 році була розроблена а у 2014-2016 року доповнена Стратегія розвитку залізничного транспорту України до 2020 р., яка передбачає реалізацію наступних стратегічних напрямків, технічне переоснащення об'єктів інфраструктури залізниць та забезпечення рухомим складом вітчизняного виробництва, здатним істотно підвищувати технікотехнологічні показники, що дозволить забезпечити прискорення руху потоків вантажів та пасажирів, товароруху, зниження транспортних витрат в економіці і їі ефективне використання по всій вертикалі управління перевезеннями на основі економічних принципів; удосконалення технології організації перевезень (перехід від принципу звітних діб до управління всім процесом, наближене до реального часу), яка використовує інноваційні технології на основі економічних принципів 3 вдуванням вимог ринку транспортних послуг, економічну оцінку експлуатаційної роботи, включаючи оптимізацію кордонів залізниць;

- впровадження швидкісного руху пасажирських поїздів;

- реформування галузі залізничного транспорту, що передбачає на першому етапі розмежування господарських функцій i функцій державного управління,створення державного господарського об'єднання на базі
Укрзалізниці, залізниць і інших підприємств, установ і організацій залізничного транспорту загального користування, а на другому - оптимізацію організаційної структури залізничного транспорту;

- удосконалення

системи формування тарифів на послуги залізничного транспорту та впровадження ринкового механізму ціноутворення у сфері вантажних та пасажирських перевезень;

- створення сприятливих умов для залучення інвестицій з метою оновлення та модернізації виробничо-технічної бази залізничного

транспорту, забезпечення розвитку державно-приватного партнерства, впровадження механізму лізингу;

- прискорення темпів інтеграції залізничного транспорту до європейської та світової транспортної системи, налагодження тісного міжнародного співробітництва, впровадження принципів європейської транспортної політики, ефективного використання вигідного географічного розташування України для збільшення обсягу транзитних перевезень;

- здійснення комплексу заходів щодо забезпечення безпеки руху поїздів та схоронності вантажів під час перевезень, зменшення негативного впливу залізничного транспорту на навколишнє природне середовище, впровадження ресурсозберігаючих технологій;

$$
\text { - удосконалення фінансово- }
$$
економічної діяльності залізниць, забезпечення прозорості;

- підвищення рівня підготовки кадрів та соціального забезпечення працівників галузі залізничного транспорту, посилення мотивації до праці; підвищення конкурентоспроможності залізниць на ринках транспортних послугу; 
- надання державної підтримки у вирішенні питань щодо закупівлі пасажирського рухомого складу, будівництва i реконструкції об'єктів інфраструктури залізниць, що мають соціальне значення та утримання збиткових дільниць. Зараз під впливом інтеграційних процесів, що відбулися у світі та розвиваються у всіх сферах українського суспільства, управління залізничною сферою та стратегія іiі розвитку також повинна зазнати суттєвих змін, зорієнтованих на досягнення європейських та світових стандартів. Тому такі стратегічні напрямки Стратегії як «прискорення темпів інтеграції залізничного транспорту до європейської та світової транспортної системи, налагодження тісного міжнародного економічного співробітництва, впровадження принципів європейської транспортної політики, ефективного використання вигідного географічного розташування України для збільшення обсягу транзитних перевезень повинні стати найпріорітетнішими.

Висновки. Таким чином, реалізація зазначених у публікації напрямків реформування залізниць у світі $\epsilon$ передумовою здійснення комплексу невідкладних завдань щодо залізничної галузі в Україні. Головнім джерелом ефективного реформування вважається урахування позитивних здобутків, отриманих залізницями зарубіжних країн. Передбачається у подальших публікаціях проаналізувати практичні кроки ПАТ «Українська залізниця» 3 метою виведення галузі із системної кризи.

\section{СПИСОК ВИКОРИСТАНИХ ДЖЕРЕЛ}

\begin{tabular}{llr}
\multicolumn{1}{c}{ 1. Иванов. } & \multicolumn{2}{c}{ Б. Шаг к } \\
национализации & как шаг & спасению \\
британских & железных & дорог \\
/Прыднепровская & магистраль. - 2002 - \\
№17. - С. 21-29 & & \\
2. Реформы на железных дорогах
\end{tabular}
Бельгии //Железные дороги мира. - 2014. №5. - С. 9-11

3. Позднякова JI.A. Соціальна економічна модель розвитку залізничного транспорту України:Автореф. Економ.наук. Харківський національний університет ім.. В.Н. Каразіна .-Х., 2002.$30 \mathrm{c}$.

4. Позднякова JI.А. Стабилизация работы железнодорожного транспорта в условиях убыточности// Бизнес форм. 2009 - №5-6.- C.64-69

5. Бараш .Ю.С. Управління залізничним транспортом України в умовах сучасного ринку.Автореф.дис...дра екон.наук. /Українська державно академії залізничного транспорту.-Х., 2007.-32c

6. Концепція впровадження швидкісного руху пасажирських поїздів на залізницях України, /Державна адміністрація залізничного транспорту України. - К., 2014. - 220с.

7. Strateqie behavior, and industrial comretition / D. j. Marris, P.J. Sinelair, N.D. Slater,J. C. Viekers //Clarendon Press, Oxford, 1986/-460p

8. Международные стратегии экономического развития /под ред. Ю В. Макогона. - :Знання, 2016 - 416с.

9. Фтиск А., Белая Книга о Транспортной политике ЕC/ А. Фрист// Транспорт.-2003.- №14(182).-С.54-55 